\title{
Articles
}

\section{Drones, The US And The New Wars In Africa}

\section{by Philip Attuquayefio}

\section{$(\mathrm{cc}) \mathrm{BY}$}

This work is licensed under a Creative Commons Attribution 3.0 License.

\begin{abstract}
Among the evolving challenges to global peace and security are the growing incidents of terrorism in Africa. With cases in Nigeria, Mali, Algeria, Somalia and Libya among others, the continent is fast earning a moniker as a major frontier in the US-led Global War on Terrorism. A key counterterrorism measure in this regard has been the controversial reliance on Drones. This paper examines terrorism in Africa and the US' response in the context of drones. It argues that notwithstanding the politico-legal conundrums, drones are a useful complement to multidimensional strategies that can yield game-changing interventions in the fight against terrorism in Africa.
\end{abstract}

\section{Introduction}

ince the early 20th Century, Africa has witnessed varying degrees of subversion from the Mau Mau nationalist campaigners in Kenya in the 1950s to acts by rebel groups in the infamous intrastate wars of Sub-Saharan Africa. While the first movement evolved mainly from political acts geared towards the struggle for independence, the latter was mostly evident in attempts to obtain psychological or strategic advantages by combatants in the brutal civil wars of Liberia, Sierra Leone, the African Great Lakes region and a number of such civil war theatres in Africa. The element of unrestrained violence commonly identified as a defining feature of terrorism (Attuquayefio, 2006), was palpable in all these movements, yet the sociopolitical or military drive for these movements barely included religion. The 1990s, however, marked the dawn of religious fundamentalism and its induced terrorism in Africa. With an overwhelming proportion of these terrorist movements tracing their foundations to Islam, a religion that is ordinarily portrayed as one of peace ironically continues to roll out some of the worst acts of terrorism in Africa. This arguably came to the limelight with the August 7, 1998 terrorist bombings of the US embassies in Nairobi and Dar es Salaam that killed over two hundred people. Subsequently in 2002, an Israeli-owned hotel in Mombasa, Kenya was attacked. (Lyman \& Morrison, 2004) The attribution of these events to the Egypt-based Islamic Jihad and other Al Qaeda surrogates such as its name sake in the Islamic Maghreb was the first public indication that international terrorist organisations were inducing affiliates on the continent. Subsequently, actions of Al-Shabaab in Somalia, the rise of Boko Haram in Northern Nigeria, the insurrection of Islamic Fundamentalists in Mali in March 2012 as well as the renewed interest in security on the continent by the US and key European countries such as the United Kingdom and France all point to Africa's emerging relevance as a frontier for the global War on Terrorism.

The US has conventionally been an advocate of global peace and security and has engineered actions, in collaboration with other countries, to guarantee this state of affairs. This notwithstanding, the post-Cold War readjustment of global alliances along the lines of geopolitical significance saw the gradual waning of US 


\section{Journal of Terrorism Research}

interest and activities in various parts of Africa. In cases like Somalia, humanitarian interventionist disasters further coalesced with this general trend to reduce US interest in Africa. Following the 9/11 attacks on the US and the consequent launch of the Global War on Terrorism, the US has renewed active interest in regions considered as brewing grounds for terrorists. The recent recalibration of US interest in Africa is, justifiably, as a result of the growing movement of terrorists on the continent.

Just like the terrorist threats, the approaches for US interventions on matters of national security have also evolved. From conspicuous full-scale military actions in the Bush and Clinton years to the "light footprints" favored by the Obama administration. The latter has involved the use of Special Forces, and other relatively more discreet approaches. A critical element of the Obama administration's counterterrorism approaches is the use of Unmanned Aerial Vehicles (UAVs) popularly known as Drones. UAVs are remotely controlled aircrafts designed with a capacity to carry a wide variety of accessories for both civilian and military use. These include long range and wide angled cameras, communication and target detection sensors and military hardware such as missiles. Added to this is the stealth ability of some drones. Consequently, they are typical for reconnaissance, surveillance and target engagement missions (Washburn \& Kress, 2009). Although, it's been suggested that experimentation with drones have been ongoing since the early 1990s, its first deployment in a context of war was in the former Yugoslavia in the mid-1990s where they were reportedly used as surveillance equipment (Turse \& Engelhardt, 2012). Subsequent evolution of drones saw its emergence as armaments for target engagement particularly in post 9/11counterterrorism activities of the US. One of the early cases in this regard was reported in Yemen in 2002, where six alleged Al Qaeda operatives were killed by drone fire (Kretzmer, 2005). Since then, it is fast gaining notoriety as the armament of choice from the options available to the US.

The use of drones has however not been without controversy both in host countries where it has, for instance, garnered political fallouts generally deemed as unfavorable to US moral leverage in global affairs, and within the domestic politics of the US, where the administration has been accused of arbitrarily authorising execution of people including some US citizens. The latter has constituted a legal conundrum that continues to attract negative publicity to the use of drones. The tactical fallouts have been suggested as far direr, namely, an increase in volunteers ready to launch a global jihad against the US and its western allies following the fabrication of drone casualties in countries such as Pakistan, Afghanistan and Yemen. (Taj, 2011)

The readiness of the US to deploy drones towards prosecuting the war on terror in Africa has long gone beyond the assumptive phase. In 2001, the US acquired and renovated Camp Lemonnier from the armed forces of Djibouti and subsequently, in May 2003, designated the facility as the base for the Combined Joint Task Force - Horn of Africa (CJTF-HOA). Since then, Camp Lemonnier has earned the reputation as a critical base for drone operations around the Horn of Africa and Yemen. In March 2013, President Obama announced further plans to set up another base in the West African country of Niger. Djibouti and Niger have been officially confirmed, yet, reports suggest that the US has access to a lot more operational ranges for drones than publicly acknowledged (Whitlock \& Miller, 2011). In terms of operability however, the first reported use of drones within the continent was a 2007 incident in which drones guided antitank missile gunships to blow down a convoy carrying one of Al Qaeda's top operatives and suspected hideout in Somalia (Axe, 2012). Since then, the US is reported to have operated drones from a number of sites in Africa including Djibouti, and Burkina Faso.

This paper utilises open source data to interrogate the state of terrorism in Africa (conceptualised as new wars) and the options applicable to the African context. It is argued that one of the ways the US can 


\section{Journal of Terrorism Research}

make game-changing interventions through surveillance and intelligence-gathering in several hotspots in Africa, without compromising its own national security is through the use of drones. The paper begins by briefly discussing the 'new wars' in Africa before making a case for the complementary utility of drones in fighting terrorism in Africa. It concludes by suggesting policy options to counter balance the utilityblighting publicity currently surrounding the use of drones in Africa. A caveat underpinning this paper is an admission by the author that the causal and sustaining factors of terrorism in Africa are multi-faceted and in most cases derive from threats to aspects of human security palpable in terrorists-generating communities. Consequently, the phenomenon can only be addressed through a multidimensional approach - one in which drones can actively feature mainly through surveillance and intelligence-gathering.

\section{Terrorism: The New Wars in Africa}

In the aftermath of the independence wars, the second major wave of conflicts on the continent-the civil wars of the post-Cold War era between the late 1980s and early 1990s saw countries like Liberia, Sierra Leone, Rwanda and Cote D'Ivoire among others witnessing a succession of violent conflicts. The consequence of these conflicts were abductions, systematic rape, genocide and a host of actions that fall within the generic description of terrorism. These acts were mainly domestic in nature and perpetrated by ethnic and political groups. It was therefore not surprising that the US maintained a general disinterest in activities in Africa during that period.

The latter part of the 1990s witnessed a marginal rise in terrorist incidents on the continent of Africa. Unlike the previous period, an overwhelming majority of these acts were attributed to the activities of Islamic extremists. The manifestations of these acts were undoubtedly ruthless yet somewhat limited to relatively few countries in East and the Horn of Africa. In the 1998 attacks on the US Embassies in Nairobi and Dar es Salaam, for instance, two hundred people are on record to have been killed and over a thousand injured. Yet in comparison to the global numbers, it was insignificant. In fact during that period, Africa placed a mere fifth, behind Latin America, Western Europe, Asia and the Middle East, as the most targeted regions for international acts of terrorism (Botha \& Solomon, 2005).

In the 21 st century, acts of terrorism in Africa have gone up exponentially (Hough, 2002). This is attributable to a number of events. One of these has had to do with the post-9/11 War on terror, and the military actions in Iraq and Afghanistan by the US and its allies. Statistics have, for instance, shown dislocation and relocation of suicide terrorist cells and training camps as well as the death or detention of several top operatives of $\mathrm{Al}$ Qaeda following the commencement of the US led War on terror (Cronin, 2003). With the disruption of its activities, Al Qaeda has adopted a more diffused approach, one that has seen the centralised command and control previously held by Osama bin Laden diffuse to other parts of the world in line with the objective to strike soft targets of the US and its western allies. With Africa playing host to monumental commercial and state interests of the US and a number of Western countries, strikes against these targets have sought to demonstrate that al Qaeda and its affiliates still retain the will and the capacity to operate around the world (Crenshaw, 2011). Relatedly, the diffusion indirectly caused by the war on terror has made the identification and neutralising of terrorist cells more difficult.

The post-independence narrative of a host of African countries has also been dominated by human insecurity arising out of the multivariate effects of poverty and general economic insecurity, environmental degradation, inadequate management of health related threats to survival as well as erosion in the significance of jealously guarded indigenous culture primarily through modernisation. These effects have been attributed to political 
instability occasioned mainly by the politics of coup d'etats as well as the tradition of woeful governance and corruption that defines leadership in many of these countries. Consequently, elements of human security have traditionally not been accorded superlative positions in the thought processes of African States relative to the desire by successive regimes to hold on to power; and where they have, in such lopsided proportions that parts of the polity are palpable left out of development. Responses to these local dynamics have evolved from largely tame protests to outright militancy and terrorism. The surge towards the terrorism end of the continuum have within the last two decades obtained motivation from the relative successes of militant groups such as the Movement for the Emancipation of the Niger Delta (MEND) in locking down national and sometimes global attention to their causes. It is therefore not surprising that Somalia, Mali and Nigeria, three of the countries in Africa severely challenged by the activities of organised terror groups have had infamous records of human insecurity in specific parts of their territories. In Nigeria for instance, Uzodike and Maiangwa (2012) describe the governance challenges as "a cocktail of widespread failures of state policies, inefficient and wasteful parastatal, and endemic corruption, poverty, unemployment, and extensive underdevelopment in the North of Nigeria". Within that context, it is not surprising that Boko Haram emerged and galvanised active membership among segments of the Northern population.

The franchising of Al Qaeda has also contributed to the increase in terrorist activities on the continent. Out of these loose arrangements, terrorists' organisations in Africa, continue to adopt and adapt the modus operandi of Al Qaeda. One of the foremost organisations depicting this franchise is Boko Haram. Operating mainly from the Northern parts of Nigeria since 2002, Boko Haram claims to be fighting for the institution of Islamic rule in Nigeria. Beyond their objective, their modes of operation; a combination of suicide attacks and car bombs in civilian areas, is dangerously similar to Al Qaeda's mode of operation.

Elsewhere on the continent, a number of terrorist organisations have engineered actions that fit within the anti-western agenda of Al Qaeda but also indicate, in some cases, the localised grievances of these groups. In North Africa for instance, Al Qaeda in Islamic Maghreb (AQIM) has been engaged in some of the high profile terrorist actions against the West and its interests as well as supporters of western ideals (Masters, 2013). Their versatility, coupled with the porous borders and vast territories in the region as well as their collaboration with other like-minded organisations in the area has resulted in an expanding trans-regional terrorist network, fast gaining reputation not just for its adopted Al Qaeda tag but also a conspicuous résumé of terrorist activities.

The West African Sub-Region is also home to two relatively recent terrorist organisations. Boko Haram operates mainly in Northern Nigeria and Cameroon, while Ansar Dine operates from Northern Mali. The former was formed in Maiduguri in 2002 as the Congregation and People of Tradition for Proselytism and Jihad (Onuoha, 2010). It is however known as Boko Haram, a Hausa moniker accorded to the group mainly on the basis of their proscription of western education. Similarly to AQIM, at foundation, the leaders of Boko Haram exploited Nigeria's governance challenges particularly relating to corruption as well as socioeconomic vulnerabilities which are more evident in the northern region to mobilise a base of followers, discontented with the status quo. With known links to AQIM (United Nations Security Council, 2014), and operating in a region with porous borders, the fear of Boko Haram expanding their influence is justified. In May 2013, a military offensive was launched against the group in Nigeria's three northern states. Aided by the declaration of curfews in some cities and air strikes on identified training camps, the military indicated that the insurgents had been "halted" (Abrak, 2013). In spite of this, experience with terror cells in other parts of the world suggest that once the underlying motif is active, the dislocation arising through the decimation is merely temporal as groups and cells relocate and often hit back in a variety of revised ways. Moreover, in the 


\section{Journal of Terrorism Research}

particular case of Nigeria, the military has gained a reputation for exaggerating successes while downplaying setbacks (Waddington, 2014). It is therefore not surprising that subsequent to the May 2013 offensive, Boko Haram has proven to be even more organised and effective, striking key targets and conducting high profile operations such as the abduction of 200 girls from a Nigerian government secondary school in April, 2014. A further threat to the region is the presence of Ansaru, a breakaway of fringe elements in Boko Haram. Ansaru has since January, 2012 sought to enforce the fight for Islamist rule. Though a smaller group, it has sought, and perhaps obtained, recognition through high profile kidnapping and execution of western targets (Onuoha, 2013).

Mali has provided another platform for brewing terrorism in Africa. With the fall of the Gaddafi regime in Libya, mercenaries armed with weapons, proliferated during the war, moved into Northern Mali where ethnic Tuaregs have been engaged in a long-running rebellion with the government in Bamako over the independence of Azawad in the North. Mobilised under the name Ansar al-Dine, this group has since 2012, engaged in various acts of terrorism, thus earning the US State Departments' categorisation as a terrorist organisation.

In the Horn of Africa, Al Shabaab continues to attract attention as arguably the continent's most prominent terrorist organisation both in terms of its links with Al Qaeda and its ability to strike at western targets or targets considered as sympathetic to the western cause or detrimental to Islam. While it is deemed as an outgrowth of the Al-Itihaad al-Islamiya (AIAI), a radical organisation that confronted the Siad Bare regime in the early 1990s, in 2003 it began its operation as the enforcing arm of the Union of Islamic Courts (ICU), when the latter took control over Mogadishu and tried to exert a level of law and order in the Somali capital that is most notable. Following the Ethiopian intervention in December 2006, ICU was all but disbanded except for the Al Shabaab that withdrew to the south Central region of the country and launched what has become a long running insurgency first, against the Ethiopians and subsequently, troops serving under the African Union Mission in Somalia. While its objective resonates as the creation of an Islamic State of Somalia, its affiliation with Al Qaeda has meant that the group has also sought to hit targets deemed as affronts to the global jihad currently been pursued by Al Qaeda and its affiliates.

The trend of terrorism around the continent is instructive of the intensifying wave of Islamic fundamentalism and the possibility of generating and sustaining training camps and recruits akin to the challenges confronted in Pakistan and Afghanistan. It also justifies the renewed focus of the US on Africa.

\section{Negotiating Drones for Africa}

The dynamics of terrorism in Africa are not lost to US policy makers. However, since the Somalia debacle in 1993, the US appears to have conceded to its relative weaknesses on the continent (Adebajo, 2003). This is related to the fact that it was not a colonial power and its actions on the continent during the Cold War were mostly limited to covert operations championed by the CIA. The history of US actions in Africa has therefore been more of covert 'drone-like' operations than open warfare such as witnessed in Iraq and Afghanistan. The current hyper predilection for drones in the US strategy is in line with the Obama Administration's "light footprints" and 'leading from behind policy'.

Admittedly, the adoption of drones is confronted by some controversies. This can be compared to those surrounding waterboarding and other interrogation techniques applied in US detention facilities (Bellamy, 2006). Unfortunately, the debate on the utility of drones in the context of terrorism is significantly challenged by what can best be described as the 'Pak Syndrome'. This is the reality that debates on the utility of drones 


\section{Journal of Terrorism Research}

are heavily influenced by their application to the war on terror in Pakistan and Afghanistan. Consequently, the application of drones are confronted by utility-blighting propaganda that merely portray drones as killer devices and negates the intelligence gathering and surveillance relevance and the impact of such intelligence to the war on terror. This includes the fact that the intelligence gathered potentially leads to the prevention of even more strikes, and by implication, more deaths by terrorists.

The Pak syndrome also dilutes the complementary capacity of drones in the war on terror by highlighting legal conundrums particularly focusing on issues concerning the responsibility to fair trial for suspects and the application of principles of humanitarian law (Alston, 2010 \& Sadat,2012) among others. These objections are often overrated and do not aptly reflect the reality that the war on terror is unconventional in many respects. Moreover, certain aspects of the African context peculiarly requires the utility of drones. In arguing the veracity of the latter, it is submitted that an analysis of the trend of terrorism in Africa, points to some continent-wide commonalities from the use of guerilla tactics, the exploitation of large expanses of geographical areas and the implications of Africa's infamous porous borders on the activities of terrorist organisations. While these illuminate the nature of the terrorist threat in Africa, it is also suggestive of the strategies that are likely to make an impact in relation to managing the phenomenon of terrorism on the continent. A number of these commonalities and their implications for drone use are examined herein.

A pronounced feature of the new wars relating to terrorism in Africa is the guerilla tactics (Onuoha, 2011) employed by the various terrorist organisations on the continent. The implication is that timeless principles of war, as espoused by the Geneva and Hague conventions, for instance, are not being adhered to. For Boko Haram, Ansar Dine, AQIM and Al Shabaab for instance, civilian targets are legitimate targets and so are injured US soldiers. The weapons of choice for terrorists have been decided more by availability and less by restrictions of Jus in Bello. A stark reminder of the abuse of legal principles is the attack on the US consulate in Benghazi, Libya, which, needless to say, was a violation of the inviolability of diplomatic premises; one of the preeminent provisions of post-Westphalia diplomatic relations. The tendency for non-state parties or their state sponsors to adhere to these rules of war undoubtedly points to the presence of an asymmetrical war. Unfortunately, the US is bound to largely adhere to the rules that terrorist organisations, herein considered as unconventional combatants, flout with impunity. In such an unfavorably unbalanced terrain, positive outcomes from the use of conventional security operatives even with regard to intelligence-gathering is dodgy.

Africa's disreputably porous borders and the prospects they offer for trans-regional terrorism is another reason why unconventional interventions by the US should be contemplated. As noted above, almost all the Islamic fundamentalist groups straddle entire regions with relative ease. In the case of Mali, it has been indicated, for instance, that porous borders to the North have facilitated the migration of fighters from Algeria-based AQIM as well as vestiges of the Libyan conflict to move in and operate with reasonable ease. The fact of mercenaries crossing the porous borders of Africa means that mobilising terror for cross-country objectives of hitting US and Western interests is made much easier (Dehez, 2010). The expanse of territory straddled, the multiplicity of countries operated in and the implications on sovereignty that the US will have to be confronted with in pursuit of terrorist and networks makes it more difficult for conventional forces to gather terrorism-related intelligence. On the contrary, the reconnaissance capacity of drones makes them ultimately efficient strategies in monitoring the flow of terrorist networks and illicit weapons as well as building of training camps in Africa. Thus essentially, managing the long porous borders could therefore benefit from the surveillance capabilities of drones. 
Related to the above is the lack of capacity of most African governments to gather and organise unimpeachable intelligence on the activities of terrorists and their networks. A number of factors account for this reality. The obvious being the lack of political commitment as manifested in the inability of governments to commit funds for developing intelligence databases countrywide and across regions. Additionally, terrorist organisations in Africa are operating on multiple fronts, adopting mutating strategies and enlisting combatants whose identities are at the least amorphous. This makes the collection of intelligence difficult and by implication, makes these wars generally less responsive to conventional deterrence strategies. In the absence of such intelligence, countries currently confronted heavily by the activities of terrorism such as Nigeria and Mali are having to depend on inadequate or inexistent intelligence to fight what is in reality, a lost battle $a b$ initio (Amaraegbu, 2013). From the determination of terrorist cells to the identification of key members and their arrest or execution, the reality is that the war on terror is fought more on intelligence and less on brute force. As such, the utility of the surveillance and intelligence-gathering capacity of drones to African governments grappling with terrorism cannot be over-emphasised.

The proliferation of weapons in Africa also makes it impossible to gauge the strategic or tactical ability of terrorist organisations. This could lead to significant miscalculations with unpredictable consequences. Particularly in Libya, where the revolutionary forces violently confronted the Gadhafi regime, the end of the war has hardly seen any meaningful programme of Disarmament, Demobilisation and Reintegration of former combatants. A number of combatants also alluded to pro-US sentiments for as long as Gadhafi was the enemy, a simple case of the enemy of my enemy being my friend. The implications of this could be obvious-the existence of many armed people fluid enough to be manipulated, proliferated arms and a growing fundamentalist rhetoric that can be mobilised for running terrorist objectives. A critical component of the US assistance to Africa as regards the war on terror must therefore relate to intelligence gathering and dissemination. The surveillance capabilities of drones are absolutely needed in these circumstances (Drew, 2010).

Related to the intelligence deficit in most African countries is an infrastructural deficit that can forestall the progress of conventional troops yet can be effectively harnessed by radical groups employing guerillastyle tactics. With vast land areas virtually undeveloped, such as the Sahel Sahara region, conventional military tactics will be confronted by accessibility challenges. Such terrain however favors the guerilla tactics of Africa's terror networks who are prone to exploit such vulnerability of conventional troops through kidnapping and suicide bombings among others. Drones on the other hand, are comparatively less prone by design to the hazards of Africa's infrastructural deficit. In this light, drones can better overcome Africa's infrastructural challenges to provide surveillance and intelligence data on terrorism.

Finally, one of the components of the war on terror since 2001 has been America's desire to win hearts and minds. Within the African continent, the US reputation appears to have floundered. Indeed, in terms of security, America's record suggests an opportunistic actor interested in the continent during the Cold War days yet quick to demarcate its interests in the aftermath of the Cold War. While this is undoubtedly symptomatic of the wiles of global politics, the re-entry of the US to Africa's security affairs based mainly on the assessed effects of African-bred terrorism and its impact on US national security should be approached with extreme caution, less funfair and more discretion. Under the circumstances, what is required is a less visible approach to intervention, one that favors the stealth operations of drones. 


\section{Journal of Terrorism Research}

\section{Considering the Anti-drone school}

The argument has been made that using drones against terrorists is not the most lasting way to fight the enemy. To the holders of this opinion, the targeted-killing of terrorists does not deter their fomentation. If a top operative is killed, for instance, it is just a matter of time before he is replaced. Also, the point is made that the more terrorists are attacked with drones, the more they pursue a correction of the asymmetry by targeting innocent civilians as they are in no position to hit back at the drones or their operators (Whetham, 2013). Consequently, it is argued that, to effectively fight terrorism particularly in Africa, the human insecurity generators of terrorism must be eliminated or at least, reduced considerably through transparency and accountability as well as equitable distribution of the national cake to primarily reduce internal dissent likely to fuel insurgencies.

This position is sound and undoubtedly reflective of the multivariate causes of terrorism in Africa. As indicated above, for instance, the post-independence corruption and mal-governance-filled narratives of the Africa State is proven to be one of the creators of terrorism in Africa. It therefore stands to reason that the search for strategies takes into consideration aspects that rectify the challenges indicated above. Unfortunately, part of the local dynamics influencing terrorism on the continent may point to the ineffectiveness of such human security and governance-inspired strategy. Presently, for instance, the leitmotif for Africa-based terrorists has shifted or is shifting from out-and-out domestic concerns to a hard lined anti-west agenda. In such a situation, one can only be dodgy about whether the terrorists remain interested in pressurising their home governments into pursuing good governance. If governance in Nigeria improves, for instance, will Boko Haram disband? Will the group abort its objective of de-secularisation of the state? In responding in the negative, this paper suggests the presence on the continent, some terrorist organisations whose evolution and motive have no relation to Africa's governance challenges, or who have moved beyond those challenges to represent a global jihad against the West and values largely considered as of western orientation. Thus, in reality, such terrorists are a bunch of 'all or nothing' intransigent killers not willing to meet anybody halfway and as such can hardly be satisfied through negotiations or good governance. This unfortunately reduces the human security and governance-inspired strategies to effective add-ons to multidimensional strategies much the same way as drones. As Olojo (2013) points out, the sources and causes of terrorism in Africa are multiple in nature and as such the best way to counter terrorism on the continent is to pursue a multi-dimensional approach.

Using drones as part of the cocktail of strategies for confronting terrorism in Africa must factor in the Pak syndrome. Civilian deaths and abuse of territorial sovereignty resulting from drone usage are legitimate concerns. Notwithstanding, they are bearable opportunity costs in the war on terrorism. Although the death of non-combatants cannot be justified in absolute terms, comparatively, incidents of terrorism are resulting in the death of more civilians than American drones have accidentally killed. Moreover, the point has been made that the civilian-casualties argument against drone usage has largely arisen due to the well-publicised quality of 'precision' drones are supposed to have. Thus, even one civilian casualty is seen as a preventable case. Such a standard cannot be achieved by any ground combat operation. Beyond the attack functions, the intelligence-gathering utility of drones is a practical tool to fight terrorism in Africa. For instance, after Boko Haram abducted about 200 girls from a high school in Chibok, China offered help by providing satellite imagery to help Nigeria track the location of the abductees. America supported with same, as well as surveillance, intelligence and reconnaissance assets. The excellence of these capacities is undoubtedly essential to combatting terrorist attacks such as the Chibok kidnapping incident. 


\section{Conclusion}

This paper is not in any way calling for a blank cheque to be issued to America to deploy its drones to Africa. That can only be inspired by the shallow assumption that all is perfect with America's deployment of drones thus far. Through a policy of Disclosure, America can fight Africa-based terrorists with drones yet not leave hanging on the necks of African states, the albatrosses of preventable civilian deaths and a wanton abuse of their territorial integrity as has been the case in Afghanistan, Pakistan and Yemen. The surveillance and intelligence-gathering functionality of drones can be deployed by America to help fight terrorism in Africa. The mention of drones should in no way be only construed as a call for targeted killings by Unmanned Aerial Vehicles. However, America should first of all, be willing to co-operate and share information with security outfits in the African states involved. If America's deployment of drones to Africa is based on their explicit consent to disclosure, it incites a careful and responsible usage on America's part and reasonable trust and support from African states. Such transparency and co-operation between America and Africa will serve greatly the security interests of both parties; make Africa as less safe for terrorists as possible and also give America a colossal upper hand in its global war on terrorism.

Africa is now a hub of terrorism. Unfortunately, the continent is inexperienced and under-prepared to fight the war unlike America. Allowing Africa to fight terrorism in a handicapped manner is risky. Not strengthening Africa's hand with an effective anti-terrorism tool like intelligence-gathering drones is akin to America shooting itself in the foot as that will leave a safe haven for terrorists and a cosy launchpad for attacking Africa and ultimately, America and its allies (Ahluwalia, 2013). Thus, it is in the interest of both parties; Africa and America to serve Africa-based terrorists doses of the same 'drone' pills that have efficiently ruffled enemy feathers elsewhere at virtually little or no risk to the lives of pro-peace soldiers. However to effectively do this, America must commit itself first to proper disclosure concerning their drone activities and also rigorously market the huge intelligence-gathering capacity of drones. The former promises a disciplined deployment on America's part while the latter counters the dominant characterisation of drones as merely killing machines. In all these, the point best drummed is that drones are merely complementary with best results likely to be felt only if the domestic concerns fuelling the recourse to terrorism are addressed.

About the author: Philip Attuquayefio holds a Doctor of Philosophy in Political Science and a Master of Philosophy in International Affairs from the University of Ghana, Legon. His research activities cover human security, terrorism and peace and conflict issues particularly as it relates to Africa. He is currently a Research Fellow at the Legon Centre for International Affairs and Diplomacy, University of Ghana.

\section{References}

Abrak, I. (2014, May 29) “Boko Haram Rebels Say Military Offensive is Failing” Reuters News Agency. Retrieved August 14,2014 from http://www.reuters.com/article/2013/05/29/us-nigeria-bokoharamidUSBRE94S0GT20130529

Adebajo, Adekeye. "Africa and America in an Age of Terror." Journal of Asian and African Studies 38.2-3 (2003): 175-191.

Ahluwalia, P. “The Mali crisis.” African Identities 11.1 (2013): 1-2.

Alston, P. (2010, May 28) Report of the Special Rapporteur on Extrajudicial, Summary or Arbitrary Executions, U.N. Doc. A/HRC/14/24/Add.6, HI 13-26. Retrieved December 18,2013 from http://www2. 


\section{Journal of Terrorism Research}

ohchr.org/english/issues/executions/annual.htm

Amaraegbu, Declan A. "Failure of Human Intelligence, Boko Haram and Terrorism in Nigeria." Journal of Sustainable Development in Africa 15.4 (2013):66-85.

Attuquayefio, P.K., "Exploring Suicide Terrorism and its Threat to International Security" Legon Journal of International Affairs 3.2 (2006): 1-19.

Axe, David (2012, August 13) "Hidden History: America's Secret Drone War in Africa”. Retrieved December 18, 2012 from http://www.wired.com/dangerroom/2012/08/somalia-drones/all/

Bellamy, Alex J. "No pain, no gain? Torture and ethics in the war on terror." International Affairs 82.1 (2006): 121-148.

Botha, A. and Solomon, H., “Terrorism in Africa.” Defense Journal 1.1 (2005):1-29.

Cilliers, J. “Terrorism and Africa.” African Security Studies 12.4 (2003): 91-103.

Crenshaw, M., .2011. Explaining Terrorism: Causes, Processes and Consequences. New York: Routledge

Hough, C., A. (2003, May 23) "Al Qaeda after the Iraq Conflict". Congressional Research Service. Retrieved November 15, 2012 from http:// fpc. State.gov/documents/organisation/21191.pdf.

Dehéz, D. "Security sector reform and intelligence services in sub-Saharan Africa: capturing the whole picture." African Security Review 19.2 (2010): 38-46.

Drew, C.(2010, January 10) "Military is awash in data from drones." New York Times. Retrieved April 12, 2013 from http://www.nytimes.com/2010/01/11/business/11drone.html?pagewanted=all\& r=0.

Lyman, Princeton N. and J. Stephen Morrison (2004, January/February) “The Terrorist Threat in Africa” January/February 2004 Foreign Affairs. Retrieved December 18,2014

http://www.foreignaffairs.com/articles/59534/princeton-n-lyman-and-j-stephen-morrison/the-terroristthreat-in-africa

Kretzmer, D. “Targeted Killing of Suspected Terrorists: Extrajudicial Executions or Legitimate Means of Defense?” European Journal of International Law 16.2(2005):171-212.

Masters, J. (2013, January 24) "Al-Qaeda in the Islamic Maghreb (AQIM)”. Retrieved June 23, 2013 from http://www.cfr.org/north-africa/al-qaeda-islamic-maghreb-aqim/p12717

Olojo, A. (2013,October) “Nigeria’s Troubled North: Interrogating the Drivers of Public Support for Boko Haram” Retrieved August 12, 2014 from http://www.icct.nl/download/file/ICCT-Olojo-Nigerias-TroubledNorth-October-2013.pdf

Onuoha, Freedom. The Islamist challenge: Nigeria’s Boko Haram crisis Explained. African Security Review, 19:2 (2010) 54-67.

Onuoha, Freedom C. "The audacity of the Boko Haram: Background, analysis and emerging trend." Security Journal 25.2 (2011): 134-151.

Onuoha, Freedom C. (2013, March 14) “Jama’atu Ansarul Musilimina Fi Biladis Sudan: Nigeria’s Evolving Terrorist Group". Retrieved December 18, 2013 from http://studies.aljazeera.net/en/

Turse, N., and Engelhardt, T., Terminator Planet: The First History of Drone Warfare 2001-2050. Charleston, SC: Dispatch Books, 2012.

Sadat, Leila Nadya. “America’s Drone Wars." Case Western Reserve Journal of International Law 45.1/2 


\section{Journal of Terrorism Research}

(2012): 215-234.

Taj, Farhat (2011) “A critical perspective on a recent survey of opinion in Pakistan's Tribal Zone." Small Wars \& Insurgencies 22.2(2011):402-413.

United Nations Security Council (2014, May 22) "Security Council Al-Qaida Sanctions Committee Adds Boko Haram to its Sanctions List” SC/11410 Retrieved August 18, 2014 from http://www.un.org/News/Press/ docs/2014/sc11410.doc.htm

Waddington, C. (2014, February) "Nigeria’s Questionable Successes against Boko Haram: West Africa - issue in Focus" Africa Conflict Monthly Monitor Feb. 2014, pages 45-49.

Washburn, A. and Moshe, K. “Unmanned Aerial Vehicles." Combat Modeling, (2009)185-210.

Whetham, D. “Killer Drones: the Moral Ups and Downs” RUSI Journal, 158.3 (2013)22-32.

Whitlock, C. and Miller, G. (2011, September 20) "US assembling secret drone bases in Africa, Arabian Peninsula, officials say." Retrieved December 12, 2013 from http://www.washingtonpost.com/world/nationalsecurity/us-building-secret-drone-bases-in-africa-arabian-peninsula-officials-say/2011/09/20/gIQAJ8rOjK story.html. 